\title{
PENGEMBANGAN PERANGKAT PEMBELAJARAN METODE OUTDOOR LEARNING UNTUK MENGEMBANGKAN PERILAKU SOSIAL ANAK USIA DINI
}

\author{
Retno Dwi Astuti ${ }^{1}$ \\ Pendidikan Islam Anak Usia Dini, Fakultas Agama Islam, \\ Universitas Islam Lamongan \\ e-mail: retnodwi.pasca@unisla.ac.id
}

\begin{abstract}
This research to describe the development of outdoor learning method learning devices through miniature outbound activities in Early Childhood Education, describing the results of the validation of outdoor learning methods through miniature outbound activities. The design of this research is research and development (R\&D). The learning device development model used in this study is to use the 4D instructional development design proposed by Thiagarajan which consists of 4 stages of development namely Define, Design, Develop, and Disseminate. The findings of this research and development are in the form of learning tools that have previously been tested, evaluated, until they meet the desired criteria. Learning tools developed include the Semester Program (Prosem), Weekly Learning Implementation Plan (RPPM) and Daily Learning Implementation Plan (RPPH).

The validation results show that the learning tool of outdoor learning methods through miniature outbound activities has a material validity level of $93 \%$, language validity of $85.71 \%$, and validity of learning experts $94.64 \%$.

Keywords : learning media, outdoor learning method, social behavior
\end{abstract}

\begin{abstract}
ABSTRAK
Penelitian ini bertujuan untuk mendeskripsikan pengembangan perangkat pembelajaran metode outdoor learning melalui miniatur kegiatan outbound pada Pendidikan Anak Usia Dini, mendeskripsikan hasil validasi perangkat pembelajaran metode outdoor learning melalui miniatur kegiatan outbound. Desain pada penelitian ini adalah penelitian dan pengembangan (R\&D). Model pengembangan perangkat pembelajaran yang digunakan dalam penelitian ini adalah menggunakan desain instructional development model 4D yang dikemukakan Thiagarajan yang terdiri dari 4 tahap pengembangan yaitu Define, Design, Develop, dan Disseminate. Adapun temuan pada penelitian dan pengembangan ini berupa perangkat pembelajaran yang
\end{abstract}


sebelumnya sudah diujicoba, dievaluasi, sampai memenuhi kriteria yang diinginkan. Perangkat pembelajaran yang dikembangkan meliputi Progam Semester (Prosem), Rencana Pelaksanaan Pembelajaran Mingguan (RPPM) dan Rencana Pelaksanaan Pembelajaran Harian (RPPH).

Hasil validasi menunjukkan bahwa perangkat pembelajaran metode outdoor learning melalui miniatur kegiatan outbound memiliki tingkat kevalidan materi 93\%,kevalidan bahasa $85,71 \%$, dan kevalidan ahli pembelajaran 94,64\%.

Kate Kunci : perangkat pembelajaran, metode outdoor learning, perilaku sosial

\section{PENDAHULUAN}

Pendidikan merupakan infestasi jangka panjang yang tak ternilai harganya. Infestasi pendidikan berupa ilmu dan nilai-nilai karakter untuk menjadi bekal generasi yang berkualitas. Tujuan pendidikan merupakan bagian dari tujuan nasional seperti yang tercantum dalam pembukaan UUD 1945, yang berbunyi "Mencerdaskan Kehidupan Bangsa". Berdasarkan pembukaan UUD 1945 tersebut maka perlulah pendidikan untuk mewujudkan bangsa yang cerdas dan dapat bersaing dengan bangsa yang lain.

Membangun bangsa yang cerdas dimulai dari pendidikan sejak anak usia dini. Anak usia dini merupakan masa yang tepat untuk melakukan pendidikan. Pada masa ini, anak sedang mengalami proses pertumbuhan dan perkembangan yang luar biasa. Anak belum memiliki pengaruh negatif yang banyak dari luar atau lingkungannya. Dengan kata lain, orang tua maupun pendidik akan lebih mudah mengarahkan anak menjadi lebih baik (Muhammad Fadlillah, 2012: 61). Proses pendidikan akan jauh lebih mengena bila dimulai dari usia dini. Banyak ahli yang sudah meneliti tentang proses perkembangan anak usia dini, menemukan bahwa masa keemasan merupakan masa yang potensial untuk tahap merangsang segala aspek perkembangannya. Sehingga diperlukan pendidikan anak usia dini untuk dapat membentuk kematangan aspek-aspek perkembangan anak agar dapat bermanfaat hingga kelak dewasa.

Anak usia dini adalah sosok individu yang sedang menjalani proses suatu perkembangan dengan pesat dan fundamental bagi kehidupan selanjutnya. Anak usia dini berada pada rentang usia 0-6 tahun. Menurut Berk (dalam Sujiono, 2009: 6) pada masa ini proses pertumbuhan dan perkembangan dalam berbagai aspek sedang mengalami masa yang cepat dalam rentang perkembangan hidup manusia. Proses pembelajaran sebagai bentuk perlakuan yang diberikan kepada anak harus memperhatikan karakteristik 
yang dimiliki setiap tahapan perkembangan anak (Sujiono, 2009:6).

Layanan pendidikan anak usia dini memfasilitasi pembelajaran yang dirancang dengan menggunakan sentra untuk mengembangkan potensi-potensi anak. Sentra merupakan pengelolaan kelas yang terpusat pada satu kegiatan dan ditangani oleh satu orang guru sercara khusus. Tujuan diterapkannya sistem sentra ini adalah mudah, tidak tergantung dengan tempat, anak dapat belajar berbagai kemampuan dalam satu waktu, bahan-bahan mudah didapat, serta dapat dilakukan secara kelompok besar.

Pembelajaran outdoor learning melalui miniatur kegiatan outbound pada sentra bahan alam ini memungkinkan anak melakukan kegiatan yang bervariasi. Kegiatan pada outdoor learning melalui miniatur kegiatan outbound pada sentra bahan alam sangat menarik bagi anak karena anak dapat menggali kemampuannya untuk mencoba berkreasi dengan bahan alam yang telah tersedia, selain itu kegiatan di dalamnya juga bervariasi karena terdapat miniatur kegiatan outbound yang sangat menarik bagi anak, khususnya anak usia dini.

Perilaku sosial adalah kegiatan yang berhubungan dengan orang lain, kegiatan yang berkaitan dengan pihak lain yang memerlukan sosialisasi dalam hal bertingkah laku yang dapat diterima oleh orang lain, serta upaya mengembangkan sifat sosial yang layak diterima oleh orang lain. Perilaku sosial pada anak usia dini ini diarahkan untuk pengembangan sosial yang baik, seperti kerjasama, tolong menolong, berbagi, simpati, empati, dan saling membutuhkan satu sama lain. Untuk itu, sasaran pengembangan perilaku sosial pada anak usia dini ini ialah untuk keterampilan berkomunikasi, keterampilan memiliki rasa senang dan periang, menjalin persahabatan, memiliki etika dan tata karma yang baik. Dengan demikian, materi pembelajaran pengembangan sosial yang diterapkan di taman kanak-kanak meliputi: disiplin, kerjasama, tolong menolong, empati, dan tanggungjawab (Susanto, 2011: 137).

Secara spesifik, Hurlock (1980: 118) mengklasifikasikan pola perilaku sosial pada anak usia dini ke dalam pola-pola perilaku sosial sebagai berikut:

a. Meniru, yaitu agar sama dengan kelompok, anak meniru sikap dan perilaku orang yang sangat ia kagumi. Anak mampu meniru perilaku guru yang diperagakan sesuai dengan tema pembelajaran.

b. Persaingan, yaitu keinginan untuk mengungguli dan mengalahkan orang lain. Persaingan ini biasanya sudah tampak pada usia empat tahun. Anak bersaing dengan teman untuk meraih prestasi seperti berlombalomba dalam memperoleh juara dalam suatu permainan, menunjukkan antusiasme dalam mengerjakan sesuatu sendiri. 
c. Kerjasama, mulai usia tahun ketiga terakhir, anak mulai bermain secara bersama dan kooperatif, serta kegiatan kelompok mulai berkembang dan meningkat baik dalam frekuensi maupun lamanya berlangsung, bersamaan dengan meningkatnya kesempatan untuk bermain dengan anak lain.

d. Simpati, karena simpati membutuhkan pengertian tentang perasaan dan emosi orang lain, maka hal ini hanya kadang-kadang timbul sebelum tiga tahun. Semakin banyak kontak bermain, semakin banyak simpati akan berkembang.

e. Empati, seperti halnya simpati, empati membutuhkan pengertian tentang perasaan dan emosi orang lain, tetapi di samping itu juga membutuhkan kemampuan untuk membaynagkan diri sendiri di tempat orang lain. Relatif hanya sedikit anak yang dapat melakukan hal ini sampai awal masa kanakkanak akhir.

f. Dukungan sosial, menjelang berakhirnya awal masa kanak-kanak dukungan dari teman-teman menjadi lebih penting daripada persetujuan orang-orang dewasa.

g. Membagi, anak mengetahui bahwa salah satu cara untuk memperoleh persetujuan sosial ialah membagi miliknya, terutama mainan untuk anak-anak lainnya. Pada momenmomen tertentu, anak juga rela membagi makanan kepada anak lain dalam rangka mempertebal tali pertemanan dan menunjukkan identitas keakraban antar anak.

h. Perilaku akrab, anak memberikan rasa kasih sayang kepada guru dan teman. Bentuk dari perilaku akrab diperlihatkan dengan canda gurau dan tawa riang di antara anak. Anak memperlakukan gurunya sebagaimana layaknya pada orang tua sendiri, memeluk, merangkul, digendong, memegang tangan guru, dan banyak bertanya.

Selain pola perilaku sosial yang dikemukakan Hurlock di atas, maka pola perilaku sosial lainnya yang perlu diajarkan atau dikembangkan kepada anak usia dini ialah pola perilaku seperti anak mampu menghargai teman, baik menghargai milik, pendapat, hasil karya teman, atau kondisi-kondisi yang ada pada teman. Menghargai kondisi orang lain, misalnya anak tidak mnegejek atau mengisolasi anak lain yang kurang sempurna anggota tubuhnya, cacat, terdapat kekurangan dari fisik, dan psikisnya. Pengembangan perilaku sosial juga bisa diarahkan untuk mengajarkan anak untuk membantu kepada orang lain (helping other), tidak egois, sikap kebersamaan, sikap kesederhanaan, dan kemandirian, yang saat ini sikap-sikap ini sudah mulai hilang dari perhatian para pendidik, baik pada tingkat pendidikan taman kanak-kanak, maupun pada tingkat pendidikan yang lebih tinggi (Susanto, 2011: 140).

Begitu selanjutnya, bahwa perilaku sosial yang berkembang pada 
masa awal kanak-kanak merupakan perilaku yang terbentuk berdasarkan landasan yang diletakkan pada masa bayi. Sebagian lagi merupakan bentuk perilaku sosial yang baru dan mempunyai landasan baru. Banyak di antara landasan baru ini dibina oleh hubungan sosial dengan teman sebaya di luar rumah dan hal-hal yang ditonton dari televisi atau buku-buku cerita. Sehingga awal masa kanak-kanak perlu diarahkan pada bentuk perilaku sosial agar dapat menyesuaikan diri sesuai dengan perkembangan anak dan kepentingan selanjutnya (Susanto, 2011: 138).

Berdasarkan pendapat para ahli tersebut dapat disimpulkan bahwa perilaku sosial adalah segala bentuk tindakan yang dilakukan atau direncanakan untuk menolong orang lain tanpa memperdulikan motif-motif penolong. Jadi, aspek kesukarelaan dan maksud dalam melakukan suatu tindakan tertentu dalam melakukan sesuatu itu merupakan hal utama dalam perilaku sosial.

Dalam sebuah kegiatan, senantiasa memerlukan pengelolaan yang baik. Pengelolaan ini juga diperlukan dalam kegiatan pembelajaran kepada anak. Hal ini dimaksudkan agar tujuan yang diharapkan memiliki kemungkinan besar ketercapaiannya. Berbicara masalah pengelolaan berarti terkait dengan manajeman. Manajemen memiliki beberapa kegiatan. Kegiatankegiatan dalam manajamen tidak sama persis antara ahli satu dengan yang lain. Namun demikian esesnsi dari kegiatan menajemen pada dasarnya adalah perencanaan, pengorganisasian, pelaksanaan, dan control atau evaluasi. Populernya kegiaan ini dikenal dengan istilah POAC (Planning, Organizing, Actuating, dan Controlling). Perencanaan pembelajaran yang jelas memiliki tujuan dan sasaran yang jelas. Kejelasan tujuan dan sasaran, akan memberi arah yang jelas tentang aktifitas yang dilakukan dalam proses belajar, dan juga asesmen yang dilakukan terhadap anak. Untuk itu keberadaan perencanaan dalam kegiatan pembelajaran anak sangat penting. Children who attend wellplanned, highquality early childhood programs in which curriculum aims are specified and integrated across domains tend to learn more and are better prepared to master the complex demands of formal schooling. (Barbara T. Boowman, dkk., 2001).

Anak anak yang mengikuti program anak usia dini yang terencana dengan baik dan berkualitas dimana tujuan kurikulumnya jelas dan lintas domain yang terintegrasi: 1) cenderung untuk belajar lebih dan 2) lebih siap untuk menguasai permintaaan yang komplek dari sekolah formal. Ini menunjukkan pentingnya ada perencanaan yang baik agar anak dapat belajar lebih. Perencanaan penyelenggaraan PAUD meliputi Program Semester (Prosem), Rencana Pelaksanaan Pembelajaran Mingguan 
(RPPM) dan Rencana Pelaksanaan Pembelajaran Harian (RPPH).

Program Semester biasanya disebut dengan istilah Prosem. Sejak terbitnya Standar PAUD, sebelum membuat Prosem, lembaga PAUD membuat Program Tahunan atau Prota terlebih dahulu. Perencanaan pembelajaran yang selama ini ada, baik Prosem, RPPM, dan RPPH memiliki kelemahan. Pada tataran RPPH seringkali diketahui tidak ada beda antara RPPH antara model pembelajaran kelompok dengan model pembelajaran Sentra.

Perangkat pembelajaran merupakan alat perlengkapan yang digunakan guru dalam melakukan aktivitas pembelajaran. Perangkat pembelajarn PAUD berupa perencanaan pembelajaran dengan segala kelengkapannya. Pengembangan

2. Rencana Pelaksanaan Pembelajaran Mingguan (RPPM)

Perencanaan program mingguan merupakan rencana kegiatan yang disusun untuk pembelajaran selama satu minggu. RPPM diturunkan dari Program Semester yang berisi sub tema, muatan atau materi pembelajaran dan rencana kegiatan. Muatan atau materi pembelajaran dikembangkan dari KD dan dihubungkan dengan tema atau sub tema yang dipilih.

3. Rencana Pelaksanaan Pembelajaran Harian (RPPH)

Rencana pelaksanaan pembelajaran harian adalah perencanaan program perangkat pembelajaran disini menunjuk pada prosedur yang dilakukan dalam membuat perencanaan pembelajaran.

Perencnaan pembelajaran PAUD berupa Prosem, RPPM, dan RPPH.

A. Perangkat Pembelajaran

1. Program Semester (Prosem)

Prosem merupakan perencanaan pembelajaran untuk satu semester. Prosem berbentuk jaringan untuk program pembiasaan maupun kemampuan dasar. Ada tiga kemampuan dasar, yaitu Kognitif Bahasa, dan Psikomotorik. Prosem merupakan perencanaan program semester berisi daftar tema satu semester yeng dikembangakan menjadi sub tema atau sub-sub tema, serta kompetensi yang ditetapkan untuk dicapai pada setiap tema, dan alokasi waktu setiap tema.

harian yang akan dilaksanakan oleh pendidik atau pengasuh pada setiap hari atau sesuai dengan program lembaga. RPPH merupakan rencana kegiatan yang disusun untuk pembelajaran selama satu hari yang berisi tema, sub tema, muatan atau materi pembelajaran dan rencana kegiatan. Muatan atau materi pembelajaran dikembangkan dari KD dan dihubungkan dengan tema atau sub tema yang dipilih.

B. Metode Penelitian

Jenis penelitian ini mengacu pada penelitian dan pengembangan (Research and Development). Fokus penelitian pengembangan untuk menghasilkan perangkat perangkat tertentu dan menguji kelayakan dan 
kepraktisan, perangkat pembelajaran tersebut. Produk yang dihasilkan dalam penelitian ini berupa perangkat pembelajaran metode outdoor learning melalui miniatur kegitan outbound dalam upaya mengembangkan perilaku sosial anak usia dini.

Model pengembangan perangkat pembelajaran yang digunakan dalam penelitian ini adalah menggunakan desain instructional development model 4D yang dikemukakan Thiagarajan yang terdiri dari 4 tahap pengembangan yaitu Define, Design, Develop, dan Disseminate.

C. Hasil dan Pembahasan

1. Analisis Perangkat Pembelajaran Metode Outdoor Learning Untuk Mengembangkan Perilaku Sosial Anak

Perangkat pembelajaran yang dikembangkan merupakan perangkat pembelajaran metode outdoor learning melalui miniatur kegiatan outbound dengan tema pekerjaan dan pada sentra bahan alam, Strategi pembelajaran sentra sendiri merupakan pembelajaran yang menekankan pada keterlibatan anak secara aktif dalam proses pembelajaran sehingga anak mampu memperoleh pengalaman belajar secara langsung dan mandiri.
Membantu anak untuk mampu memperoleh pengalaman belajar secara langsung dan mandiri maka salah satu cara yang bisa dilakukan adalah dengan mengkontekstualkan pembelajaran. Utari mengatakan untuk mengkontekstualkan pembelajaran yang sesuai dengan kehidupan sehari-hari anak maka cara yang bisa dilakukan adalah melalui penanaman nilai-nilai kerarifan lokal yang ada dilingkungan anak salah satunya dengan bahan alam.

bahwa lingkungan outdoor merupakan tempat yang sangat menarik untuk anak, di mana anak-anak dapat tumbuh dan berkembang. Saat bermain di lingkungan outdoor, banyak kemampuan anak yang dapat dikembangkan, misalnya bereksplorasi, tantangan kemampuan motorik kasar dan halus, kemampuan sosial serta kemampuan kognitif dan kemampuan dasar tentang lingkungan alam.

Senada dengan pendapat tersebut, Ancok juga berpendapat bahwa outbound adalah kegiatan di alam terbuka (outdoor), outbound juga dapat memacu semangat belajar anak. Outbound merupakan sarana penambah wawasan pengetahuan yang di dapat dari serangkaian 

$\begin{aligned} & \text { pengalaman berpetualang } \\ & \text { sehingga dapat memacu }\end{aligned}$
semangat belajar anak. Bentuk
kegiatan outbound berupa
stimulasi kehidupan berupa
permainan-permainan (games)
yang kreatif, rekreatif, dan
edukatif, baik secara individual
maupun kelompok dengan tujuan
untuk mengembangkan perilaku
anak.

Perangkat pembelajaran yang telah dikembangkan mengacu pada kurikulum 2013 PAUD. Pada kurikulum 2013 ada 4 kompetensi inti yang harus dicapai dalam pembelajaran. Pada KI 1 menjelaskan adanya sikap spiritual atau religius yang mana pembelajaran harus menyeimbangkan antara penguasaan ilmu pengetahuan dengan nilai islami yang ada pada anak, pada KI 2 menjelaskan tentang sikap social dimana setiap anak harus memiliki perilaku social sesuai perkembangan usianya, KI 3 menjelaskan tentang pengetahuan dan KI 4 menjelaskan tentang keterampilan yang harus dimiliki anak sesuai dengan perkembangan karakteristik dan usianya.

Model pengembangan perangkat pembelajaran yang digunakan dalam penelitian ini adalah menggunakan desain instructional development model
4D yang dikemukakan Thiagarajan yang terdiri dari 4 tahap pengembangan yaitu Define, Design, Develop, dan Disseminate.

Perangkat pembelajaran yang dikembangkan memiliki beberapa ciri khas yang membedakan dengan perangkat pembelajaran yang lainnya. Adapun ciri khas dari perangkat pembelajaran ini adalah:

1. Perangkat pembelajaran yang dikembangkan berbasis alam sekitar anak, sehingga memudahkan anak untuk mengkonkritkan pembelajaran dan dapat memberikan pengetahuan serta menumbuhkan rasa cinta pada lingkungan sekitar.

2. Perangkat pembelajaran yang dikembangkan dirancang dengan metode outdoor learning melalui miniatur kegiatan outbound yang sangat disengangi anak sehingga anak antusias dalam mengikuti semua kegiatan yang ada pada perangkat pembelajaran yang dikembangkan ini.

3. Perangkat pembelajaran yang dikembangkan mengambil tema Pekerjaan karena tema tersebut sangat cocok digunakan jika dibasiskan dengan kearifan lokal. Produk pengembangan perangkat pembelajaran dikembangkan melalui beberapa tahap penilaian diantaranya adalah penilaian dari ahli materi, ahli bahasa, dan ahli pembelajaran anak kelompok B di TK Muslimat Nurul Huda yang 
mana sebagai sasaran penelitian. Aspek yang dinilai diantaranya adalah mengenai kesesuaian materi dengan usia anak, kesesuain bahasa, dan keefektifan perangkat pembelajaran dalam pembelajaran. Hasil penilaian dari beberapa ahli dan tanggapan anak, kemudian dijadikan sebagai rujukan untuk penyempurnaan perangkat pembelajaran yang dikembangkan.

Berdasarkan penilaian yang dilakukan oleh beberapa ahli mendapatkan nilai yang baik, hal tersebut didasarkan pada hasil validasi ahli materi sebesar $93 \%$, hasil validasi ahli bahasa $85,71 \%$, dan penilaian guru kelompok B sebagai ahli pembelajaran sebesar 94,64\% dan penilaian anak terhadap modul sebagai subjek uji coba dengan nilai $88 \%$ dan semuanya ada dalam kategori sangat layak atau sangat valid.

Perangkat pembelajaran

yang dikembangkan secara keseluruhan penilaianya adalah sangat layak, meskipun demikian masih ada beberapa kritik dan saran yang diberikan oleh ahli sebagai penyempurnaan pada perangkat pembelajaran yang dikembangkan.

\section{KESIMPULAN}

1. Penelitian pengembangan ini telah menghasilkan perangkat pembelajaran metode outdoor learning melalui miniatur kegiatan outbound, dengan mengikuti langkah-langkah yang dikemukakan oleh Thiagarajan yang terdiri dari 4 tahap pengembangan yaitu Define, Design, Develop, dan Disseminate. Perangkat pembelajaran yang dikembangkan merupakan perangkat pembelajaran cetak yang berisi Program Semester (Prosem), Rencana Pelaksanaan Pembelajaran Mingguan (RPPM) dan rencana Pelaksanaan Pembelajaran Harian (RPPH) dengan metode outdoor learning melalui miniatur kegiatan outbound.

2. Perangkat pembelajaran metode outdoor learning melalui miniatur kegiatan outbound pada anak kelompok B TK Muslimat Nurul Huda Sekaran Lamongan memiliki tingkat efektifitas sebagai berikut:

a. Hasil validasi menunjukkan bahwa perangkat pembelajaran metode outdoor learning melalui miniatur kegiatan outbound memiliki tingkat kevalidan materi 93\%,kevalidan bahasa $85,71 \%$, dan kevalidan ahli pembelajaran 94,64\%.

\section{SARAN}

1. Perangkat pembelajaran metode outdoor learning melalui miniatur kegiatan outbound yang telah dikembangkan masih belum banyak diketahui maka dari itu hendaknya membaca petunjuk penggunaan sebelum digunakan dalam pembelajaran.

2. Penggunaan perangkat pembelajaran metode outdoor learning melalui miniatur kegiatan outbound ini jika 
digunakan sebaiknya guru mempersiapkan alat peraga yang bisa digunakan sebagai penunjang pemerolehan konsep/materi supaya pembelajaran menjadi lebih bermakna.

\section{DAFTAR PUSTAKA}

Ancok, Djamaludin. 2002. Outbound Management Training. Yogjakarta: UII Press Yogjakarta.

Arikunto. 2006. Prosedur Penelitian Suatu Pendekatan Praktik. Jakarta: Rhineka Cipta

Asmawati, Luluk. 2008. Pengelolaan Kegiatan Pengembangan Anak Usia Dini. Jakarta: Universitas Terbuka.

Badiatul, Muchisin Asti. 2009. Fun Outbound-Merancang Kegiatan Outbound yang Efektif. Yogjakarta: Diva Press.

Bilton, Hellen. 2005. Learning Outdoor "Improving the Quality of Young Children Play Outdoor". London: David Fulton Publisher.

$\begin{array}{rrr}\text { Hurlock. } & 1980 . & \text { Psikologi } \\ \text { Perkembangan } & \text { Suatu } \\ \text { Pendekatan } & \text { Sepanjang } & \text { Rentang }\end{array}$

Kehidupan (terj.). Jakarta: Erlangga.

Husamah. 2013. Pembelajaran Luar Kelas Outdoor Learning. Jakarta: Prestasi Pustaka.

Santyasa, I. W. 2009. Pembelajaran Berbasis Masalah dan Pembelajaran Kooperatif. Jakarta: Departemen Pendidikan Nasional.

Sugiyono. 2010. Metode Penelitian Pendidikan (Pendekatan Kuantitatif, Kualitatif, dan $R \& D)$. Bandung: Alfabeta.

Sujiono, Yuliani Nurani. 2009. Konsep Dasar pendidikan Anak Usia Dini. Jakarta: Indeks.

Susanto, Ahmad. 2011. Perkembangan Anak Usia Dini; Pengantar dalam Berbagai Aspeknya. Jakarta: Kencana.

Suyanto, Slamet. 2005. Konsep Dasar Pendidikan Anak Usia Dini. Jakarta: Depdiknas.

Yuliarto, Dwi. 2010. Bermain Sambil Belajar Sains di Taman Kanak-kanak. Jakarta: Indeks. 
PEDAGOGI: Jurnal Anak Usia Dini dan Pendidikan Anak Usia Dini

Volume 5 Nomor 2 Agustus 2019

P-ISSN: 2599-0438; E-ISSN: 2599-042X 